\title{
Direito Penal do Consumidor: Venda de mercadorias impróprias para o consumo
}

\section{Consumer criminal law: sale of goods unfit for comsunption}

Artur de Brito Gueiros Souza ${ }^{1}$

Carlos Eduardo Adriano Japiassú ${ }^{2}$

\section{RESUMO:}

Analisa o crime de venda de mercadoria imprópria para o consumo, descrito no art. 7o, IX, da Lei no 8.137/1990, examinando a controvérsia doutrinária e jurisprudencial sobre a natureza jurídica e a necessidade de realização de laudo pericial, afirmando a impropriedade do produto. Conclui no sentido de que o crime contém elemento normativo do tipo e não se caracteriza como norma penal em branco.

\section{PALAVRAS-CHAVE:}

Consumidor - mercadoria imprópria ao consumo - Tipicidade.

\section{ABSTRACT:}

Analyzes the crime of selling improper merchandise for consumption, described in art. 7, IX, of Law no. 8.137 / 1990, examining the doctrinal and jurisprudential controversy over the legal nature and the need for an expert report, affirming to the impropriety of the product. Concludes that the crime contains a normative element and is not characterized as a blank criminal standard.

KEYWORDS:

Consumer - improper merchandise for consumption - actus reus.

\footnotetext{
${ }^{1}$ Professor de Direito Penal da UNESA e da UERJ.

2 Professor de Direito Penal da UNESA, da UERJ e da UFRJ. 


\section{INTRODUÇÃO}

Larvas de barata, teias de aranha, insetos dentro de garrafas de suco, refrigerante com embalagem mofada, preservativo em lata de extrato de tomate, anel dentro de biscoito infantil, fezes de rato em pão francês ${ }^{3} \ldots$ O consumidor brasileiro que sai a procura de matériaprima ou mercadoria para a sua refeição ou, ainda, que se senta em um bar ou restaurante para comer, coloca-se - o mais das vezes de maneira desapercebida - na condição de vítima de uma das infrações mais importantes de todo o ordenamento jurídico-penal, pois alimento é pressuposto de vida e saúde. Na sabedoria cristã, é o pão nosso de cada dia.

De fato, situações como essas, que atentam contra os direitos do consumidor, ocorrem frequentemente no nosso cotidiano, sendo que os casos que são comunicados às autoridades constituem apenas uma gota d'água no oceano de abusos praticados por empresários, comerciantes ou seus prepostos. Como bem dito por Antônio Herman V. Benjamin, no contexto da criminalidade de consumo, a Justiça penal deve ter em mente que a quantidade de fraudes e abusos praticados contra consumidores que lhe chega ao conhecimento é diminuta, quando comparada ao número de ataques que ocorrem diariamente na sociedade de consumo. É neste contexto que a punição penal ganha grande relevo educativo. $^{4}$

Imbuído desse propósito de disciplinar por intermédio do Direito Penal as graves violações nas relações entre fornecedor e consumidor de mercadorias - em especial os alimentos - cumpre destacar a norma tipificada no inc. IX, do art. $7^{\circ}$, da Lei n. 8.137/1990. Constitui crime contra as relações de consumo: vender, ter em depósito para vender ou expor à venda ou, de qualquer forma, entregar matéria-prima ou mercadoria, em condições impróprias ao consumo.

Em que pese a relevância da presente temática - que guarda relação com princípios insculpidos na Constituição da República ${ }^{5}$-, é forçoso reconhecer que há grande controvérsia doutrinária e jurisprudencial a respeito do alcance normativo do crime de venda de

3 Cf. https://www.conjur.com.br/2018-out-15/veja-stj-julgado-casos-alimentos-contaminados, acessado abril 2019.

4 BENJAMIN, Antônio Herman V. Introdução à criminalidade de consume. In Direito Penal Empresarial. Rocha, Valdir de Oliveira (Coord.). São Paulo: Dialética, 1995, p. 40.

$5 \quad$ Cf. art. $5^{\circ}$, inc. XXXII - "O Estado promoverá, na forma da lei, a defesa do consumidor"; art. 170 - "A ordem econômica, fundada na valorização do trabalho humano e na livre iniciativa, tem por fim assegurar a todos existência digna, conforme os ditames da justiça social, observados os seguintes princípios: $\mathrm{V}$ - defesa do consumidor." 
mercadoria imprópria para o consumo. Tratar-se de crime de perigo abstrato ou concreto, demandando, no último caso, a feitura de laudo pericial? É norma penal em branco ou a expressão "condições impróprias ao consumo" seria elemento normativo do tipo?

Sem qualquer pretensão de originalidade, este trabalho tem por finalidade discorrer sobre tais questões, com o objetivo de contribuir ao debate de assunto de grande relevância teórica e prática. Para tanto, parte-se da análise do tipo penal do art. $7^{\circ}$, da Lei n. 8.137/1990. Em seguida, são expostas as correntes doutrinárias relativas à natureza jurídica do crime do inc. IX, do art. $7^{\circ}$, da Lei n. 8.137/1990. No item subsequente, apresentam-se as orientações jurisprudenciais existentes no Tribunal de Justiça do Estado do Rio de Janeiro, no Superior Tribunal de Justiça e no Supremo Tribunal Federal. Por fim, é feita uma síntese reflexiva acerca da matéria, no escopo de responder às indagações contidas no parágrafo anterior.

Antes de encerrar esse tópico inicial, importa agregar que as normas que definem crimes contra as relações de consumo pertencem ao Direito Penal Econômico em sentido amplo. Conforme já ressaltado, há que se distinguir o Direito Penal Econômico em sentido estrito - o reforço de normas penais para assegurar o Direito Administrativo - do Direito Penal Econômico lato sensu - isto é, a regulação jurídico-penal de toda a cadeia de produção, fabricação, circulação e consumo de bens e serviços, ou vale dizer, todo o "acontecer econômico". ${ }^{6}$ Essa circunstância não pode ser olvidada pelo aplicador ou intérprete que se depara com o tipo penal do inc. IX, do art. $7^{\circ}$, da Lei n. 8.137/1990.

\section{ANÁLISE DO TIPO DO ART.7º, DA LEI N. 8.137/1990}

A Lei n. 8.137, de 27/12/1990, originou-se do Projeto de Lei n. 4.788-A, de 1990, encaminhado ao Congresso Nacional pelo Presidente da República, por intermédio da Mensagem n. 340/1990. ${ }^{7}$ Segundo José Geraldo Brito Filomeno, na origem dessa lei se encontravam as Medidas Provisórias 153 e 156, que cuidavam, respectivamente, de "crimes de abuso do poder econômico" e "crimes contra a Fazenda Pública". Embora objeto de ação

6 Cf. SOUZA, Artur de Brito Gueiros. Da Criminologia à Política Criminal: Direito Penal Econômico e o novo Direito Penal. In Inovações no Direito Penal Econômico. __ (Org.). Brasília: ESMPU, 2011, p. 120. Sobre o assunto: TIEDEMANN, Klaus. El concepto de Derecho económico, de Derecho Penal económico y de delito económico. In Cuadernos de Política Criminal, n. 28, Edersa, Madri, 1986, p. 72. BAJO FERNÁNDEZ, Miguel. Concepto de Derecho Penal económico. In Diccionario de Derecho Penal Económico. Boix Reig, Javier (Dir.). Madrid: Iustel, 2008, p. 168.

7 Cf. ANDRADE, Pedro Ivo. Crimes contra as relações de consumo. Curitiba: Juruá, 2008, p. 82. Revista Juris Poiesis - Rio de Janeiro. Vol.22-n²8, 2019, pg.190 - 207. ISSN 2448-0517 
direta de inconstitucionalidade interposta pela Procuradoria-Geral da República, aquelas Medidas Provisórias também serviram de base ao projeto da Lei n. 8.137/1990. ${ }^{8}$

Deve-se salientar a sobreposição de diplomas legais que - no mesmo momento histórico - passaram a tutelar o Direito Penal do Consumidor: a Lei n. 8.078/1990 (Código de Defesa do Consumidor) e a já mencionada Lei n. 8.137/1990. Com efeito, a Lei por último mencionada, promulgada no dia 27/12/1990, entrou em vigor no dia 28/12/1990, ao passo que a Lei n. 8.078/1990, promulgada no dia 11/09/1990, entrou em vigor depois de ultrapassado o prazo de vacatio legis de 180 dias, ou seja, em 12/03/1991. Em outras palavras, versando, em parte, sobre o mesmo objeto - crimes contra as relações de consumo -, a Lei n. 8.137/1990 entrou em vigência no período de vacância legal do Código de Defesa do Consumidor, causando discussões sobre supostos conflitos de leis penais no tempo, bem assim conflitos aparentes de normas penais, o que exigiu grande esforço doutrinário e jurisprudencial para harmonizar e acomodar os dois textos legislativos.

No tocante aos ilícitos definidos nos nove incisos do art. $7^{\circ}$, da Lei n. 8.137/1990, o bem jurídico protegido são as relações de consumo. Segundo João Marcello de Araujo Jr., relações de consumo são aquelas nas quais figuram um fornecedor de bens e um consumidor que, como tal, os adquire para atendimento direto de uma necessidade própria ou de um grupo de pessoas a ele diretamente vinculadas. Tais relações se inserem no mercado de consumo, ou seja, no conjunto de pessoas e empresas que procuram e oferecem produtos e serviços, estabelecendo com isso as condições em que executarão as relações entre elas, as posições de fornecedores e consumidores. ${ }^{9}$

Nas figuras típicas contidas no art. $7^{\circ}$, da Lei n. 8.137/1990, o sujeito ativo é o fornecedor que - consoante a lição de Pedro Ivo Andrade - pode se apresentar como comerciante, revendedor, distribuidor, fabricante etc. Segundo o Autor, trata-se de crime próprio ou especial, ou seja, aquele que pressupõe no agente uma particularidade ou condição pessoal; no caso, a qualidade de fornecedor. ${ }^{10}$ Segundo, ainda, Pedro Ivo Andrade, por se tratar de crime próprio, não caracteriza o tipo do inc. IX, do art. $7^{\circ}$, da Lei n. 8.137/1990, a conduta do particular que não possua essa condição, como, por exemplo, no caso de uma pessoa que venha adquirir determinada mercadoria em um supermercado e, por descuido,

$8 \quad$ FILOMENO, José Geraldo Brito. Crimes contra o consumidor: Art. $7^{o}$ da Lei 8.137 x Código de Defesa do Consumidor. In Revista Brasileira de Ciências Criminais, n. 21, São Paulo, 1999, p. 226.

9 ARAUJO JR., João Marcello de. Dos crimes contra a ordem econômica. São Paulo: Revista dos Tribunais, 1995, p. 99-100. No mesmo sentido: FONSECA, Antonio Cezar Lima da. Direito Penal do Consumidor. Porto Alegre: Livraria do Advogado, 1999, p. 250.

$10 \quad$ ANDRADE, Pedro Ivo. Op. cit., p. 101.

Revista Juris Poiesis - Rio de Janeiro. Vol.22-n²8, 2019, pg.190 - 207. ISSN 2448-0517

Rio de Janeiro, 29 de abril de 2019. 
deixa expirar o prazo de validade do produto sem consumi-lo e, na sequência, ciente do vencido prazo de validade, voluntariamente resolve distribuí-lo a seus vizinhos carentes. ${ }^{11}$

A respeito do sujeito passivo - como ocorre nos crimes contra as relações de consumo -, tem-se que é a coletividade (vitimização difusa) e, eventualmente, um consumidor atingido pela conduta do sujeito ativo, como pode ocorrer no tipo do inc. IX, do art. $7^{\circ}$, da Lei ora analisada. Como dito por Damásio de Jesus, na hipótese em que o consumidor aparece como sujeito passivo secundário, a norma penal incriminadora, protegendo o interesse difuso, tutela, por via reflexa, os interesses individuais, como a vida, a saúde, o patrimônio etc. ${ }^{12}$

Como antecipado, o tipo objetivo compreende nove condutas. Art. $7^{\circ}$ - Constitui crime contra as relações de consumo: I - favorecer ou preferir, sem justa causa, comprador ou freguês, ressalvados os sistemas de entrega ao consumo por intermédio de distribuidores ou revendedores; II - vender ou expor à venda mercadoria cuja embalagem, tipo, especificação, peso ou composição esteja em desacordo com as prescrições legais, ou que não corresponda à respectiva classificação oficial; III - misturar gêneros e mercadorias de espécies diferentes, para vendê-los ou expô-los à venda como puros; misturar gêneros e mercadorias de qualidades desiguais para vendê-los ou expô-los à venda por preço estabelecido para os demais mais alto custo; IV - fraudar preços por meio de: a) alteração, sem modificação essencial ou de qualidade, de elementos tais como denominação, sinal externo, marca, embalagem, especificação técnica, descrição, volume, peso, pintura ou acabamento de bem ou serviço; b) divisão em partes de bem ou serviço, habitualmente oferecido à venda em conjunto; c) junção de bens ou serviços, comumente oferecidos à venda em separado; d) aviso de inclusão de insumo não empregado na produção do bem ou na prestação dos serviços; V elevar o valor cobrado nas vendas a prazo de bens ou serviços, mediante a exigência de comissão ou de taxa de juros ilegais; VI - sonegar insumos ou bens, recusando-se a vendê-los a quem pretenda comprá-los nas condições publicamente ofertadas, ou retê-los para o fim de especulação; VII - induzir o consumidor ou usuário a erro, por via de indicação ou afirmação falsa ou enganosa sobre a natureza, qualidade do bem ou serviço, utilizando-se de qualquer meio, inclusive a veiculação ou divulgação publicitária; VIII - destruir, inutilizar ou danificar matéria-prima ou mercadoria, com o fim de provocar alta de preço, em proveito próprio ou de terceiros; IX - vender, ter em depósito para vender ou expor à venda ou, de qualquer forma, entregar matéria-prima ou mercadoria, em condições impróprias ao consumo; Pena -

$11 \quad$ Idem, p. 101-102.

12 JESUS, Damásio E. de. Natureza jurídica dos crimes contra as relações de consumo. In Ciência Penal. Coletânea de Estudos em Homenagem a Alcides Munhoz Netto. Curitiba: JM Editora, 1999, p. 86-87. 
detenção, de 2 (dois) a 5 (cinco) anos, ou multa. Parágrafo único. Nas hipóteses dos incisos II, III e IX pune-se a modalidade culposa, reduzindo-se a pena e a detenção de 1/3 (um terço) ou a de multa à quinta parte.

De acordo com a doutrina, a maior parte das condutas típicas contempladas no art. $7^{\circ}$, da Lei n. 8.137/1990, constitui uma atualização de normas penais similares que existiam na Lei n. 1.521/1951 (Lei de Economia Popular). Nesse sentido, José Geraldo Brito Filomeno assinala que a origem remota da Lei n. 8.137/1990 foram os estudos elaborados no ano de 1984 por comissão designada pelo então Ministro da Justiça, que foram incumbida de rever a Lei n. 1.521/1951, de molde a atualizá-la, bem como criar tipos novos dentro da nova realidade econômica, política e social. ${ }^{13}$

Especificamente sobre o inc. IX, do art. $7^{\circ}$, da Lei n. 8.137/1990, cuidou-se de aprimoramento legislativo da conduta então tipificada no art. 175, inc. I, do Código Penal (fraude no comércio). Por conta disso, a doutrina entende que ocorreu a revogação tácita daquele dispositivo do Código Penal. Nesse sentido, Luiz Regis Prado, interpretando a ação típica do inc. IX, do art. $7^{\circ}$, da Lei n. 8.137/1990, considera não mais subsistir o crime de fraude no comércio. Segundo aquele Autor, se a lei posterior que disciplina os crimes perpetrados nas relações de consumo trata da venda pelo comerciante de mercadoria falsificada ou deteriorada, como se fosse verdadeira ou perfeita, não subsiste dúvida de que a norma anterior se encontra revogada. ${ }^{14}$

Sobre o tipo subjetivo nos ilícitos do art. $7^{\circ}$, da Lei n. 8.137/1990, ele é composto pelo dolo, isto é, a vontade consciente de praticar as elementares do tipo objetivo, abrangendo - nas palavras de Luiz Regis Prado - não apenas o escopo a que visou o agente, mas também os meios por ele utilizados. Em alguns incisos não basta apenas o dolo, pois é imprescindível o elemento subjetivo do injusto. Demais disso, há previsão de punição na modalidade culposa, dentre outras, na hipótese do inc. IX, do art. $7^{\circ}$, da Lei n. 8.137/1990, conforme se observa do parágrafo único daquele tipo penal. ${ }^{15}$

Por fim, acerca da consumação e tentativa, é certo existir diversidade de situações nos citados incisos do artigo em questão, o que não permite maior aprofundamento dogmático, considerando as restrições de espaço do presente trabalho científico. Com relação

13 FILOMENO, José Geraldo Brito. Op. cit., p. 226. No mesmo sentido: ANDRADE, Pedro Ivo. Op. cit., p. 106.

$14 \quad$ Cf. PRADO, Luiz Regis. Direito Penal Econômico. $8^{\mathrm{a}}$ ed. Rio de Janeiro: Forense, 2019, p. 120. No mesmo sentido: SOUZA, Artur de Brito Gueiros; JAPIASSÚ, Carlos Eduardo A. Direito Penal. Volume Único. Rio de Janeiro: Forense, p. 713-714.

$15 \quad$ PRADO, Luiz Regis. Op. cit., p. 120.

Revista Juris Poiesis - Rio de Janeiro. Vol.22-n²8, 2019, pg.190 - 207. ISSN 2448-0517

Rio de Janeiro, 29 de abril de 2019. 
ao inc. IX, do art. $7^{\circ}$, tem-se que esta modalidade típica se aperfeiçoa quando o agente vende ou mantém em depósito para vender ou expor à venda ou, de qualquer forma, entregar matéria-prima ou mercadoria em condições impróprias ao consumo. A tentativa é admissível nas hipóteses de vender e entregar; nas demais, não. ${ }^{16}$

\section{ORIENTAÇÕES DOUTRINÁRIAS SOBRE O CRIME DA VENDA DE MERCADORIA IMPRÓPRIA PARA O CONSUMO}

Conforme adiantado, há grande controvérsia acerca da natureza jurídica do crime do art. $7^{\circ}$, inc. IX, da Lei n. 8.137/1990. Para uma primeira corrente doutrinária, seria crime de perigo abstrato ou presumido, que se perfaz com a mera realização da conduta descrita no tipo. Para a segunda corrente, trata-se de crime de perigo concreto, sendo, portanto, necessária a realização de exame pericial para atestar a nocividade do objeto material para com o bem juridicamente tutelado. ${ }^{17}$

A razão do dissenso doutrinário repousaria no tipo penal do art. 62, da Lei n. 8.078/1990 (Código de Defesa do Consumidor), que fora objeto de veto presidencial. O referido dispositivo possuía a seguinte redação: “Art. 62. Colocar no mercado, fornecer ou expor para fornecimento produtos ou serviços impróprios. Pena: Detenção de seis meses a dois anos e multa. $\S 1^{\circ}$ Se o crime é culposo: Pena: Detenção de três meses a um ano ou multa. $\S 2^{\circ}$ As penas deste artigo são aplicáveis sem prejuízo das correspondentes à lesão corporal e à morte."

O Presidente da República, por intermédio da Mensagem n. 664, endereçada ao Presidente do Senado Federal, entendeu por bem em vetar aquele dispositivo legal, apresentando a seguinte justificativa: "Em se tratando de norma penal, é necessário que a descrição da conduta vedada seja precisa e determinada. Assim, o dispositivo afronta a garantia estabelecida no art. $5^{\circ}$, XXXIX, da Constituição.”18

Todavia, a decisão presidencial de veto foi alvo de críticas da doutrina, e por um par de razões. A uma, porque o art. 62, do CDC não continha descrição vaga ou indeterminada,

\footnotetext{
$16 \quad$ Idem, p. 123.

17 A propósito, leciona Renato de Mello Jorge Silveira que a característica que tradicionalmente define os crimes de perigo abstrato reside na ausência de perigo no tipo. Este não menciona o perigo entre seus elementos, mas se limita a definir uma ação perigosa, pois entende que o surgimento do perigo se deduz da realização de uma ação com essas características. (SILVEIRA, Renato de Mello Jorge. Direito Penal Econômico como Direito Penal de Perigo. São Paulo: Revista dos Tribunais, 2006, p. 119).

18 Cf. http://www.planalto.gov.br/ccivil_03/LEIS/Mensagem_Veto/anterior_98/vep664-L8078-90.htm, acessado abril 2019.
} 
mas, sim, incompleta. Vale dizer, cuidava-se de norma penal em branco, cujo complemento era dado pelos arts. $18, \S 6^{\circ}$, e $20, \S 2^{\circ}$, do mesmo diploma legal. Não havia, portanto, ofensa ao princípio da legalidade, conforme os ensinamentos de José Geraldo Brito Filomeno. ${ }^{19}$ Ademais, havia tipos penais no projeto de lei encaminhado para sanção do Poder Executivo com conteúdo muito mais indeterminado, imprecisos ou lacunosos, e que tampouco foram objeto de veto. Cite-se, por exemplo, o art. 65, do CDC: executar serviço de alto grau de periculosidade, contrariando determinação de autoridade competente. Esse tipo penal não esclarece o que seria "alto grau de periculosidade". Nesse sentido, Eliana Passarelli sustenta que a técnica legislativa adotada para a redação do art. 62, da Lei 8.078 não comprometia, em razão do preceito não padecer de imprecisão ou indeterminação, já que seu necessário complemento vinha disposto no próprio Estatuto. Tratava-se, portanto, de norma penal em branco lato sensu. ${ }^{20}$

Aparentemente inconformado com o veto do Poder Executivo, o Poder Legislativo inseriu semelhante incriminação no rol dos ilícitos do art. $7^{\circ}$, da Lei n. 8.137/1990, consoante o mencionado inc. IX, e que não foi objeto de veto presidencial. Ocorre, porém, que as elementares do tipo do inc. IX, não primaram pela melhor técnica legislativa, gerando dificuldades interpretativas. Por exemplo, não se utilizou qualquer vírgula entre os termos "ter em depósito para vender ou expor à venda", de modo que - nas palavras de Pedro Ivo Andrade - não se sabe se a intenção do legislador era punir a conduta de "expor à venda" ou de "ter em depósito para expor a venda", o que torna o tipo de difícil compreensão. ${ }^{21}$

Feita essa digressão - e retornando a questão central desse estudo -, parte da doutrina considera que o tipo penal do inc. IX, do art. $7^{\circ}$, da Lei n. 8.137/1990 se trata de crime de perigo abstrato, isto é, que não exige lesão ou dano para a sua caracterização. Contenta-se com a só potencialidade lesiva. Dentre outros, é esse o entendimento de Alberto Silva Franco et al. Segundo suas palavras, parece que a só superação do prazo de validade do produto já caracteriza o crime, mostrando-se desimportante se a mercadoria, posta ou permanecendo à venda após o decurso do seu prazo de validade é, ou não, imprópria para o consumo ou mostra-se deteriorada ou tenha perdido o seu princípio ativo. ${ }^{22} \mathrm{Na}$ mesma linha, Pedro Ivo

19 FILOMENO, José Geraldo Brio. Op. cit., p. 236.

20 PASSARELLI, Eliana. Dos crimes contra as relações de consumo. São Paulo: Saraiva, 2002, p. 47.

21 ANDRADE, Pedro Ivo. Op. cit., p. 116. Segundo o Autor, melhor seria se o legislador tivesse utilizado a técnica empregada no art. 276, do Código Penal: Vender, expor à venda, ter em depósito para vender ou, de qualquer forma, entregar a consumo (...). (Idem, ibidem).

${ }_{22}$ FRANCO, Alberto Silva et al. Leis penais especiais e sua interpretação jurisprudencial. Vol. $1.7^{\mathrm{a}} \mathrm{ed}$. São Paulo: Revista dos Tribunais, 2001, p. 1480. 
Andrade entende que o crime em questão é de perigo abstrato, se aperfeiçoando com a realização da quaisquer das condutas nele prevista (vender, ter em depósito para vender, expor a venda ou entregar matéria-prima ou mercadoria em condições impróprias ao consumo). ${ }^{23}$

Em sentido contrário, há quem considere tratar-se de crime de perigo concreto, cuja exposição ao dano deve ser demonstrada pericialmente. Para Guilherme de Souza Nucci, considera-se que ter matéria-prima ou mercadoria em condições impróprias ao consumo é situação que deixa vestígio material. Por conta disso, aquele Autor entende ser indispensável a realização de exame pericial para atestar se a mercadoria ou a matéria-prima, realmente, pela avaliação de especialistas, é imprópria para ao consumo. ${ }^{24}$ De maneira similar, Roberto Delmanto et al sustentam que a locução "condições impróprias ao consumo" conduz a sérias divergências doutrinárias e jurisprudenciais. De todo modo, para estes Autores, tem-se como mais correta a posição no sentido de ser indispensável a realização de perícia que comprove, efetivamente, a danosidade da mercadoria ou da matéria-prima à saúde. ${ }^{25}$

Por sua vez, Damásio de Jesus, após lembrar a Recomendação feita no XIII Congresso Internacional de Direito Penal, realizado no Cairo em 1984, no sentido de que o emprego de tipos delitivos de perigo abstrato seria aconselhável como meio válido para a luta contra a delinquência econômica, considera que as infrações contra as relações de consumo naturalmente incluído o inc. IX, do art. $7^{\circ}$ - seriam espécies de crime de dano. Contudo, o Autor esclarece que, em sua opinião, o dano ou lesão refere-se ao interesse jurídico e não ao objeto material do delito. Sendo assim, a essência dos delitos contra as relações de consumo está na lesão ao interesse jurídico da coletividade, que se consubstancia nas próprias relações de consumo, não pertencendo necessariamente ao tipo incriminador a lesão ou perigo de dano a eventual objeto material individual dos consumidores. ${ }^{26}$

De toda sorte, a doutrina majoritária sustenta que o crime do inc. IX, do art. $7^{\circ}$, da Lei n. 8.137/1990, é norma penal em branco. Como expresso por Luiz Regis Prado, trata-se de norma penal em branco, já que a matéria-prima ou mercadoria consideradas impróprias ao consumo encontram-se mencionadas no Código de Defesa do Consumidor (art. 18, § $6^{\circ}$ ). ${ }^{27}$ No

23 ANDRADE, Pedro Ivo. Op. cit., p. 120.

24 NUCCI, Guilherme de Souza. Leis penais e processuais penais comentadas. Vol. 1. $7^{\text {a }}$ ed. São Paulo: Revista dos Tribunais, 2013, p. 536.

25 DELMANDO, Roberto et al. Leis penais especiais comentadas. Rio de Janeiro: Renovar, 2006, p. 356.

26 JESUS, Damásio E. de. Nova visão da natureza dos crimes contra as relações de consumo. In Revista Brasileira de Ciências Criminais, n. 4, São Paulo, p. 86-87.

27 PRADO, Luiz Regis. Op. cit., p. 119. Dispõe o art. 18, § 6 ${ }^{\circ}$, do CDC: São impróprios ao uso e consumo: I - os produtos cujos prazos de validade estejam vencidos; II - os produtos deteriorados, alterados, adulterados, avariados, falsificados, corrompidos, fraudados, nocivos à vida ou à saúde, perigosos ou, ainda, Revista Juris Poiesis - Rio de Janeiro. Vol.22-n²8, 2019, pg.190 - 207. ISSN 2448-0517 
mesmo sentido, Pedro Ivo Andrade assinala que o inc. IX alude a matéria-prima ou mercadoria "em condições impróprias ao consumo", cujo complemento é extraído do art. 18, $\S 6^{\circ}$, do Código de Defesa do Consumidor. ${ }^{28}$

\section{ENTENDIMENTOS JURISPRUDENCIAIS SOBRE A QUESTÃO}

Não só a doutrina, mas, igualmente, a jurisprudência brasileira não é uniforme acerca da presente questão. Em geral, os julgados dividem-se em dois grupos. Para o primeiro, a conduta do comerciante que expõe a venda matéria-prima ou mercadoria com condições impróprias ao consumo - p. ex., com o prazo de validade vencido -, se adéqua à figura típica do art. $7^{\circ}$, inc. IX, da Lei n. 8.137/1990. Por conta disso, não seria preciso, depois da apreensão do produto pela fiscalização sanitária, a elaboração de laudo pericial acerca da sua impropriedade. Numa palavra, o delito seria de perigo abstrato.

Nesse sentido, a $2^{\text {a }}$ Câmara Criminal do Tribunal de Justiça do Estado do Rio de Janeiro (TJRJ), ao julgar apelação interposta contra condenação por crime do art. $7^{\circ}$, inc. IX, da Lei n. 8.137/1990, fixou entendimento no sentido de que se cuida de crime de perigo abstrato. Isso porque, cumpriria ao empresário ou comerciante atentar para o dever de cuidado, não oferecendo para o consumidor mercadorias impróprias e com prazo de validade vencido. Dessa maneira, para caracterização do crime seria desnecessária a elaboração de laudo pericial, sendo suficiente que o material apreendido confirme a sua impropriedade. ${ }^{29}$

Em outro julgado do mesmo Tribunal - conhecido como o caso de "fezes de rato no pão francês" -, a $1^{\text {a }}$ Câmara Criminal chegou ao mesmo entendimento. Isto porque, a simples comprovação, por parte dos agentes públicos, da forma como o produto era manipulado sem as devidas condições de higiene, constituiu-se fundamento empírico suficiente para a tipificação da conduta - ao menos a título de negligência -, independentemente de se comprovar aquisição ou consumo por qualquer consumidor. ${ }^{30}$

aqueles em desacordo com as normas regulamentares de fabricação, distribuição ou apresentação; III - os produtos que, por qualquer motivo, se revelem inadequados ao fim a que se destinam.

28 ANDRADE, Pedro Ivo. Op. cit., p. 119. No mesmo sentido: PASSARELLI, Eliana. Op. cit., p. 47.

29 ACrim. n. 200705000997. 2 $2^{\text {a }}$ Câmara Criminal do TJERJ. Relator Des. José Magalhães Peres.

http://www1.tjrj.jus.br/gedcacheweb/default.aspx?UZIP=1\&GEDID=0003C6EFB055C18EC EA61327175731BBEA0010A1C3603131\&USER=, acessado abril 2019.

30 ACrim. n. 200605000056. $1^{\text {a }}$ Câmara Criminal do TJERJ. Relator Des. Antonio Carlos 
Todavia, em sentido contrário, no mesmo TJRJ encontram-se arrestos contemplando entendimento de que não se trata de crime de perigo abstrato ou presumido, visto ser indispensável a realização de exame pericial para a comprovação da impropriedade da mercadoria para consumo. Neste sentido, entendeu a $5^{\text {a }}$ Câmara Criminal ao julgar apelação interposta contra condenação imposta pela $2^{\mathrm{a}}$ Vara Criminal da Comarca de Duque de Caxias, num caso em que o comerciante expunha a venda mercadoria com prazo de validade vencido. Conforme contido neste arresto, uma coisa é a presunção legal de que o produto está impróprio para consumo pelo fato de estar vencido seu prazo de validade, outra, diferente, é estar realmente impróprio para o consumo, o que para efeitos criminais demanda exame laboratorial. ${ }^{31}$

A $7^{\text {a }}$ Câmara Criminal do TJRJ entendeu, igualmente, no sentido da necessidade de perícia para comprovar a impropriedade da mercadoria para o consumo, com a demonstração ou constatação de sua má qualidade ou mau estado de conservação. Isso porque o simples vencimento do prazo de validade constante no rótulo do produto seria mero indicador dado pelo fabricante para exigir maior atenção do usuário no seu consumo, possibilitando, de fato, a sua apreensão, se for o caso, ou sua devolução ao fabricante. Dessa maneira, seria evidente que mesmo antes da data afixada pelo fabricante pode o produto encontrar-se impróprio, como é possível sua higidez mesmo após seu vencimento. ${ }^{32}$

A controvérsia jurisprudencial também se instalou no Superior Tribunal de Justiça (STJ). Com efeito, para a $5^{\mathrm{a}}$ Turma daquele Tribunal, o tipo do inc. IX, do art. $7^{\circ}$, da Lei $\mathrm{n}$. 8.137/1990 trata-se de hipótese que, para sua concretização, basta que se coloque em risco a saúde de eventual consumidor da mercadoria. Dessa maneira, cuida-se de crime de perigo abstrato, sendo desnecessária a constatação, via laudo pericial, da impropriedade do produto para o consumo. ${ }^{33}$

http://www1.tjri.jus.br/gedcacheweb/default.aspx?UZIP=1\&GEDID=0003896FAEB82654D0 FE64B24D6D1E165FA64D44C33C314F\&USER=, acessado abril 2019.

31 ACrim. n. 2006.050.02332. 5 Câmara Criminal do TJRJ. Relatora Des. Maria Christina L. de Góes. In http://www1.tjrj.jus.br/gedcacheweb/default.aspx?UZIP=1\&GEDID=0003966BDAB04190F88A86C64067924C 7E2E7AC8C361490B\&USER=, acessado abril 2019.

$32 \quad$ ACrim. 2002.050.04975, $7^{\mathrm{a}}$ Câmara Criminal do TJRJ. Relator Des. Eduardo Mayr. In http://www1.tiri.jus.br/gedcacheweb/default.aspx?UZIP=1\&GEDID=000372740C15414DDC3BC389830F87C3 51D29E4CC3373D26\&USER=, acessado abril 2019.

REsp. 1163095. 5 ${ }^{a}$ Turma. Relator Min. Gilson Dipp. Pub. DJe de 22/11/2010. No mesmo sentido: "1.Consoante jurisprudência consolidada nesta Egrégia Corte, o delito tipificado no art. $7^{\circ}$, inciso IX, da Lei n. 8.137/90, é um crime formal e de perigo abstrato, ou seja, que não exige lesão ou dano, contentando-se com a mera potencialidade lesiva. 2 . No caso, foi realizada uma vistoria por órgãos oficiais, que atestaram a presença de $500 \mathrm{~kg}$ (quinhentos quilogramas) de carne bovina abatida sem inspeção e em desacordo com a legislação vigente." (REsp. 1111672. 5a Turma. Relatora Min. Laurita Vaz. Pub. DJe de 30/11/09). 
Na mesma Turma, em acórdão datado de dezembro de 2018, repetiu-se o entendimento no sentido de que se trata de crime de perigo abstrato, restando a materialidade do caso sob análise comprovada com a expiração do prazo de validade de algumas das mercadorias apreendidas no estabelecimento comercial, à luz da norma penal do art. $7^{\circ}$, inc. IX, da Lei n. 8.137/1990, combinado com art. 18, § 6º incs. I e II, da Lei n. 8.078/1990. Dessa maneira, se a própria legislação consumerista considera imprestável para utilização os produtos com a data de validade expirada ou em desacordo com as normas de distribuição ou apresentação, revela-se totalmente improcedente o argumento de que seria necessária a realização de exame pericial de natureza diversa da que foi realizada, sendo suficiente a constatação de que o prazo de validade dos produtos já se encontrava expirado no momento da apreensão, bem como de que alguns deles estariam embalados em desacordo com as

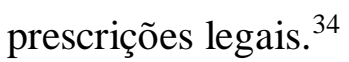

Em sentido contrário, a $6^{\mathrm{a}}$ Turma do STJ é assente em considerar que a caracterização do crime previsto no art. $7^{\circ}$, inc. IX, da Lei n. 8.137/1990 depende de realização de laudo pericial atestando a impropriedade dos produtos, no intuito de comprovar a inequívoca nocividade para o consumo, mesmo se expirado o seu prazo de validade. Sendo assim, conquanto parte da doutrina e da jurisprudência entendam que o delito em questão seja de perigo abstrato, aquela Turma do STJ considera que há necessidade de feitura de exame pericial nos produtos pretensamente impróprios, a fim de que seja comprovada a sua real nocividade para consumo humano, sob pena de inaceitável responsabilidade penal objetiva. ${ }^{35}$

Na mesma $6^{\text {a }}$ Turma, deu-se provimento a recurso ordinário interposto para trancar o andamento de ação penal, por ausência de justa causa, de um caso apreciado pelo Tribunal de Justiça de Santa Catarina, relativa a apreensão, realizada em conjunto por órgãos de fiscalização estadual e federal, de mais de seiscentos quilos de alimentos, alegadamente com os respectivos prazos de validades vencidos. Na hipótese, aquela Turma considerou que, ante a inexistência de prova pericial, produzida diretamente sobre os produtos alimentícios apreendidos, seria insuficiente a conclusão pela impropriedade para o consumo exclusivamente em virtude da ausência de informações obrigatórias na rotulagem do produto ou em decorrência do prazo de sua validade estar vencido. Sendo assim, ausente a prova da

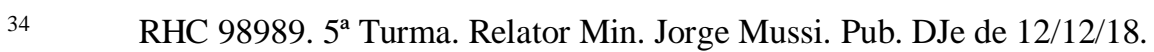

35 HC 388374. 6a Turma. Relator Min. Antonio Saldanha Palheiro. Pub. DJe de 01/12/17. No mesmo sentido: “1. A venda de produtos impróprios ao uso e consumo constitui delito que deixa vestígios, sendo indispensável, nos termos do art. 158, do Código de Processo Penal, a realização de exame pericial que ateste que a mercadoria efetivamente é imprópria para o consumo, não bastando, para tanto, mero laudo de constatação." (REsp. 1556132. 6 Turma. Relatora Min. Maria Thereza de Assis Moura. Pub. DJe de 31/03/16). 
materialidade do crime, a eventual responsabilização e punição pelo descumprimento de normas relativas à conservação e exposição, para venda, dos gêneros alimentícios apreendidos no estabelecimento comercial, estaria reservada apenas ao âmbito dos Direitos Administrativo e Civil, não ao Direito Penal. ${ }^{36}$

Em pesquisa realizada no repertório de jurisprudência do Supremo Tribunal Federal (STF) é possível encontrar acórdãos em ambas as posições. Com efeito, em julgado realizado pela $1^{\text {a }}$ Turma do STF, no ano de 2000 , restou consignado que a tipificação da figura penal definida no art. $7^{\circ}$, inc. IX, da Lei n. 8.137/1990, por ser norma penal em branco, foi adequadamente preenchida pelo art. $18, \S 6^{\circ}$, inc. I, do Código de Defesa do Consumidor, que define como impróprio ao uso e consumo produto cujo prazo de validade esteja vencido. Por conseguinte, a exposição à venda de produto em condições impróprias ao consumo - no caso concreto, oito quilos de farinha de trigo com prazo de validade expirado - já configura o delito, que se consuma com a simples ação do agente, sendo dispensável a comprovação da impropriedade material. ${ }^{37}$

Posteriormente, a $2^{\text {a }}$ Turma do STF apreciou um caso envolvendo gerentes de uma unidade industrial de produtos da linha Coca-Cola, que teriam concorrido para a colocação no mercado de duas garrafas de dois litros do refrigerante Coca-Cola em condições impróprias ao consumo, posto que envasilhadas em embalagens avariadas e com fungos. Na ocasião, a Corte Suprema - prestigiando a tese de delito de perigo abstrato -, considerou caracterizado o ilícito do art. $7^{\circ}$, inc. IX, da Lei n. 8.137/1990, afastando a alegação de princípio da insignificância a defesa considerava insignificante a apreensão de duas garrafas de Coca-Cola no universo de 320 mil produzidas a cada dia -, tendo em conta que as condutas atentariam, de imediato, contra as relações de consumo, bem jurídico que pode ser violado com a colocação quer de uma, quer de uma centena de mercadorias impróprias no mercado. ${ }^{38}$

Entretanto, quando do julgamento de Habeas Corpus impetrado contra acórdão do STJ que proveu recurso especial do Ministério Público do Paraná, restabelecendo a condenação dos pacientes como incursos no delito do inc. IX, do art. $7^{\circ}$, da Lei n. 8.137/1990, a $1^{\text {a }}$ Turma do STF adotou posição contrária às acima esposadas. Com efeito, neste julgamento, fixou-se o entendimento de que o crime do inc. IX, do art. $7^{\circ}$, da Lei $n$. 8.137/1990, é norma penal em branco, a ter seu conteúdo preenchido, no caso, pela norma do 
inc. II, do $\S 6^{\circ}$, do art. 18 da Lei $\mathrm{n}^{\circ}$ 8.078/90, que dispõe serem impróprios para consumo os produtos fabricados em desacordo com as normas regulamentares de fabricação, distribuição ou apresentação. Todavia, a criminalização da conduta exigiria do titular da ação penal a comprovação da impropriedade do produto para uso, o que não teria sido feito. Dessa forma, por considerar imprescindível a realização de exame pericial para aferir a nocividade dos produtos apreendidos, aquela Turma concedeu habeas corpus aos pacientes. ${ }^{39}$

\section{TOMADA DE POSIÇÃO: NORMA PENAL EM BRANCO VS. ELEMENTO NORMATIVO DO TIPO}

Leciona Klaus Tiedemann que as características próprias da vida cotidiana condicionam uma série de particularidades na configuração técnica do Direito Penal Econômico, distinguindo-o, de forma bastante clara, do Direito Penal tradicional. Dentre essas particularidades do Direito Penal Econômico - ramo do Direito que, como dito na Introdução desse trabalho, abrange o Direito Penal do Consumidor e, obviamente, o crime de venda de mercadoria imprópria ao consumo -, reside não só na tutela de bens jurídicos supraindividuais ou coletivos, bem assim na utilização de crimes de perigo abstrato, mas também na adoção de técnicas especiais de tipificação, tais como as normas penais em branco e os elementos normativos do tipo, estes últimos por Tiedemann também denominados de "pequenas cláusulas gerais". 40

Assim, é natural que haja certa dúvida ou imprecisão ao se tomar determinada partícula de um tipo penal que incide sobre quaisquer dos segmentos do Direito Penal Econômico - como as relações de consumo - como sendo indicativa de norma penal em branco, a ser complementada pela normativa proveniente do Direito Administrativo. Isso porque, pode-se estar diante de tipo penal cujo conteúdo demandaria tão-somente a atividade valorativa do caso concreto, isto é, diante de um elemento normativo do tipo. Como bem assinalado por Klaus Tiedemann, na análise de um crime econômico não raro se depara com o difícil problema de delimitar e distinguir normas penais em branco dos elementos normativos

39 HC 90779. $1^{\text {a }}$ Turma. Relator Min. Carlos Britto. Pub. DJ de 24/10/08.

40 TIEDEMANN, Klaus. La técnica legislativa del Derecho Penal Económico. In Derecho Penal y nuevas formas de criminalidad. __. Lima: Grijley, 2007, p. 82. 
do tipo, devendo-se, para tanto, adotar vários critérios que, infelizmente, não são úteis em todos os casos. ${ }^{41}$

Discorrendo sobre o crime em questão, Patrick Couto Xerez Sobral esclarece que não é correto considerar o inc. IX, do art. $7^{\circ}$, da Lei n. 8.137/1990, como norma penal em branco, cujo complemento seria dado pela definição de mercadoria imprópria para consumo, nos termos do art. 18, $\S 6^{\circ}$, da Lei n. 8.078/1990 (Código de Defesa do Consumidor). Isso porque, este último dispositivo definiria produtos impróprios ao consumo para fins apenas cíveis e comerciais, não podendo ser utilizado para complementar o delito acima referido. ${ }^{42}$ Segundo o Autor, o art. $18, \S 6^{\circ}$, da Lei n. 8.018/1990 insere-se no contexto da responsabilidade do fornecedor por vício do produto, estipulando os produtos impróprios ao consumo, dentre eles, aquele que se mostrar com o prazo de validade vencido, o que, se comprovado no caso concreto, seria suficiente para desencadear a sistemática da responsabilidade objetiva por vício do produto do CDC, mas não para constituir um injusto penal. Ou seja, o simples fato de um produto estar fora da validade não significa que esteja estragado, já que os fabricantes fixam o prazo de validade menor, com folga, para impedir que se deteriore no lapso indicado ou, ainda, para manter o frescor do produto ofertado nas prateleiras. ${ }^{43}$

De forma similar, Flavia Siqueira discorre sobre o que seriam produtos considerados impróprios para o consumo (art. $7^{\circ}$, inc. IX, da Lei n. 8.137/1990). Depois de registrar que o conteúdo dessa expressão seria vago, a Autora diz que, em geral, a doutrina e a jurisprudência brasileira costumam adotar o caminho mais fácil, afirmando que aquela norma penal seria complementada pelo Código de Defesa do Consumidor que, em seu art. 18, § 6 ${ }^{\circ}$, estabeleceria o que seriam produtos impróprios para o uso e consumo. Todavia, seria questionável valer-se do art. $18, \S 6^{\circ}$, do CDC, como complemento da norma penal do inc. IX, do art. $7^{\circ}$, da Lei n. 8.137/1990, pois, do contrário, poderia se chegar ao absurdo de considerar a mera exposição culposa à venda de um produto fora da validade, mas que não ofereça in concreto qualquer risco para a saúde do consumidor, como criminosa. ${ }^{44}$

41 TIEDEMANN, Klaus. Manual de Derecho Penal Económico. Parte General y Especial. Valencia: Tirant lo Blanch, 2010, p. 102-103.

42 SOBRAL, Patrick Couto Xerez. Notas sobre o crime de mercadoria imprópria para consumo. In Estudos de ciências criminais em homenagem à Professora Patrícia Glioche. Ramos, Patrícia Pimentel de O. (Org.). Rio de Janeiro: Lumen Juris, 2019, p. 128.

43 Idem, p. 129.

44 SIQUEIRA, Flavia. Responsabilidade penal pelo produto e imputação. Delimitação de âmbitos de responsabilidade na empresa pela produção e comercialização de produtos defeituosos ou 'impróprios para o consumo'. In Comentários ao Direito Penal Econômico brasileiro. Martinelli, João Paulo O.; Santos, Humberto Souza (Org.). Belo Horizonte: D’Plácido, 2018, p. 216-218. 
Dito isso, pode-se considerar a norma contida no inc. IX, do art. $7^{\circ}$, da Lei n. 8.137/1990, não como uma norma penal em branco - a ser complementada, em tese, pelo art. 18 , $\S 6^{\circ}$, da Lei n. 8.078/1990 -, mas sim um crime que contempla elementos normativos extrajurídicos - matéria-prima ou mercadoria em condições impróprias ao consumo -, cujo alcance deve ser extraído pelo julgador no exame do caso concreto. ${ }^{45}$ A propósito, elementos normativos do tipo podem ser definidos como as expressões típicas cuja exata compreensão demanda uma atividade valorativa no próprio campo da tipicidade. Não seriam apreendido de imediato - como ocorre com os elementos descritivos do tipo -, exigindo, para o seu exato alcance, um juízo de valor de caráter social, cultural ou jurídico. ${ }^{46}$

Imagine-se, por exemplo, uma situação na qual os agentes de fiscalização venham a encontrar, em um estabelecimento comercial, alimentos contendo fezes de roedores na farinha ou no pão, carne bovina exalando odor ou, ainda, potes de iogurte em mau estado e sem refrigeração - tudo comprovado por auto de vistoria e laudo de apreensão e constatação de local. Estas circunstâncias fáticas dariam o conteúdo valorativo dos elementos normativos do tipo do inc. IX, do art. $7^{\circ}$, da Lei n. 8.137/1990, tomando-os como preenchidos pelo magistrado sentenciante. Ora, exigir-se, nesse caso, a feitura de exame pericial para atestar a impropriedade do produto para o consumo humano parece configurar não somente desnecessário formalismo - quando não um "dogmatismo" - que não se coadunaria com o escopo de proteção do bem jurídico relações de consumo.

Por outro lado, em uma hipótese fática de infração administrativa que redundasse na apreensão de pacotes de biscoito ou embalagens de carne de frango congelada, com alguns poucos dias de expiração do prazo de validade, e que, um exame de viso, tais mercadorias aparentassem estar aptas para o consumo humano, parece correto que o julgador - para extrair o significado fático das elementares normativas em causa -, venha a perquirir da acusação a existência de laudo pericial atestando a real impropriedade dos produtos ofertados para o público consumidor, sob pena de trancamento da ação penal por falta de justa causa. Nesse caso, não seria juridicamente correto considerar que o crime do inc. IX, do art. $7^{\circ}$, da Lei n. $8.137 / 1990$, seria norma penal em branco, cujo complemento viesse a ser automaticamente dado pelo art. 18, $\S 6^{\circ}$, inc. I, da Lei n. 8.078/1990 (produtos com prazos de validade vencidos), contentando-se somente com a informação sobre a expiração da data regular de consumo daqueles alimentos.

$45 \quad$ Nesse sentido: SOBRAL, Patrick Couto Xerez. Op. cit., p. 129.

46 SOUZA, Artur de Brito Gueiros; JAPIASSÚ, Carlos Eduardo A. Op. cit., p. 165.

Revista Juris Poiesis - Rio de Janeiro. Vol.22-n²8, 2019, pg.190 - 207. ISSN 2448-0517

Rio de Janeiro, 29 de abril de 2019. 
Em síntese: mercadoria imprópria para o consumo é elemento normativo do tipo e não norma penal em branco do crime de perigo abstrato do inc. IX, do art. $7^{\circ}$, da Lei n. $8.137 / 1990$.

\section{REFERÊNCIAS BIBLIOGRÁFICAS}

ANDRADE, Pedro Ivo. Crimes contra as relações de consumo. Curitiba: Juruá, 2008.

ARAUJO JR., João Marcello de. Dos crimes contra a ordem econômica. São Paulo: Revista dos Tribunais, 1995.

BAJO FERNÁNDEZ, Miguel. Concepto de Derecho Penal económico. In Diccionario de Derecho Penal Económico. Boix Reig, Javier (Dir.). Madrid: Iustel, 2008.

BENJAMIN, Antônio Herman V. Introdução à criminalidade de consume. In Direito Penal Empresarial. Rocha, Valdir de Oliveira (Coord.). São Paulo: Dialética, 1995.

DELMANTO, Roberto et al. Leis penais especiais comentadas. Rio de Janeiro: Renovar, 2006.

FILOMENO, José Geraldo Brito. Crimes contra o consumidor: Art. $7^{\circ}$ da Lei 8.137 x Código de Defesa do Consumidor. In Revista Brasileira de Ciências Criminais, n. 21, São Paulo , 1999.

FONSECA, Antonio Cezar Lima da. Direito Penal do Consumidor. Porto Alegre: Livraria do Advogado, 1999.

FRANCO, Alberto Silva et al. Leis penais especiais e sua interpretação jurisprudencial. Vol. 1. $7^{\mathrm{a}}$ ed. São Paulo: Revista dos Tribunais, 2001.

JESUS, Damásio E. de. Natureza jurídica dos crimes contra as relações de consumo. In Ciência Penal. Coletânea de Estudos em Homenagem a Alcides Munhoz Netto. Curitiba: JM Editora, 1999.

Nova visão da natureza dos crimes contra as relações de consumo. In Revista Brasileira de Ciências Criminais, n. 4, São Paulo.

NUCCI, Guilherme de Souza. Leis penais e processuais penais comentadas. Vol. $1.7^{\mathrm{a}}$ ed. São Paulo: Revista dos Tribunais, 2013.

PASSARELLI, Eliana. Dos crimes contra as relações de consumo. São Paulo: Saraiva, 2002, p. 47.

PRADO, Luiz Regis. Direito Penal Econômico. 8a ed. Rio de Janeiro: Forense, 2019.

SILVEIRA, Renato de Mello Jorge. Direito Penal Econômico como Direito Penal de Perigo. São Paulo: Revista dos Tribunais, 2006. 
SIQUEIRA, Flavia. Responsabilidade penal pelo produto e imputação. Delimitação de âmbitos de responsabilidade na empresa pela produção e comercialização de produtos defeituosos ou 'impróprios para o consumo'. In Comentários ao Direito Penal Econômico brasileiro. Martinelli, João Paulo O.; Santos, Humberto Souza (Org.). Belo Horizonte: D’Plácido, 2018.

SOBRAL, Patrick Couto Xerez. Notas sobre o crime de mercadoria imprópria para consumo. In Estudos de ciências criminais em homenagem à Professora Patrícia Glioche. Ramos, Patrícia Pimentel de O. (Org.). Rio de Janeiro: Lumen Juris, 2019.

SOUZA, Artur de Brito Gueiros; JAPIASSÚ, Carlos Eduardo A. Direito Penal. Volume Único. Rio de Janeiro: Forense, 2018.

SOUZA, Artur de Brito Gueiros. Da Criminologia à Política Criminal: Direito Penal Econômico e o novo Direito Penal. In Inovações no Direito Penal Econômico. (Org.). Brasília: ESMPU, 2011.

TIEDEMANN, Klaus. El concepto de Derecho económico, de Derecho Penal económico y de delito económico. In Cuadernos de Política Criminal, n. 28, Edersa, Madri, 1986.

La técnica legislativa del Derecho Penal Económico. In Derecho Penal y nuevas formas de criminalidad. . Lima: Grijley, 2007.

. TIEDEMANN, Klaus. Manual de Derecho Penal Económico. Parte General y Especial. Valencia: Tirant lo Blanch, 2010.

Submetido em: 23/03/2019

Aceito em: 27/03/2019 